\title{
Acute viral hepatitis: aetiology and evolution
}

\author{
C B CHOW, ${ }^{*}$ T $\mathrm{T}$ Y LAU, ${ }^{*} \mathrm{~N}$ K LEUNG, ${ }^{*}$ AND W K CHANG $\dagger$ \\ ${ }^{*}$ Paediatric A Unit, Princess Margaret Hospital, and †Medical and Health Department Virus Unit, Queen \\ Mary Hospital, Hong Kong
}

SUMMARY Over a period of three and a half years, 348 consecutive children with acute hepatitis were studied. There were 205 boys and 143 girls aged from 3 months to 12 years old. The most common type was hepatitis $\mathrm{A}$, of which there were 281 cases, $81 \%$ of the total; there were 41 in the under 4 years old age group (63\% of that group), 99 in the $5-8$ year old age group ( $87 \%$ of that group) and 141 in the $8-12$ year old age group ( $83 \%$ of that group). Hepatitis B occurred in $29(8 \%$ of the total), and non-A, non-B hepatitis occurred in $35(10 \%)$. All the children with hepatitis A and all but one with hepatitis $B$ recovered. There were three deaths from fulminant hepatitis, one in the group with hepatitis B and two with non-A, non-B. Clearance of the hepatitis B surface antigen was fast, by six months 26 patients having cleared the antigen and $21(77 \%)$ being positive for hepatitis B surface antibody. One patient became a carrier of hepatitis B surface antigen.

Acute viral hepatitis is a serious health problem in many countries, but there are few data on the aetiology and course of the infection in children. The purpose of the present study was to find out the incidence of the various types of the disease in Hong Kong and monitor the course of the infection.

\section{Patients and methods}

From March 1983 to September 1986, 348 consecutive patients were admitted to this unit with acute viral hepatitis. The diagnosis was made if the patients gave histories of characteristic symptoms, and if there were signs of acute viral hepatitis with abnormal liver function tests. Only patients with viral hepatitis were included in the study.

The following information was recorded for each patient: sex, age, any recent injections, any recent transfusion of blood products, family history of hepatitis, recent contact with someone with hepatitis, recent journeys abroad, consumption of shellfish, any drugs taken, and the state of hygiene in the home. Samples of blood were taken on admission and during the second week in hospital for estimations of full blood count, platelet and reticulocyte count, erythrocyte sedimentation rate $(\mathrm{mm}$ in the first hour), glucose-6-dehydrogenase activity, prothrombin time, partial thromboplastin time, liver and renal function tests, glucose and complement C3 concentrations, and serological markers for hepatitis.

In addition, liver function tests were carried out weekly while the patient was in hospital and at one month, three months, six months, nine months, 12 months, and three monthly thereafter until the results returned to normal. Serological markers that were measured included anti-hepatitis A virus IgM, anti-hepatitis A virus IgG, hepatitis B surface antigen and antibody, anti-hepatitis B core IgM, anti-hepatitis B core and e antigen and antibody, and antibodies against Epstein-Barr virus, cytomegalovirus, and herpes simplex virus.

Diagnosis of hepatitis A was confirmed by the presence of anti-hepatitis A virus IgM on enzyme linked immunosorbent assay; of hepatitis $B$ by the presence of anti-hepatitis B core IgM (Corzym M or Corab), or the presence of hepatitis B surface antigen on reverse passive haemagglutination or radioimmunoassay followed by seroconversion on radioimmunoassay (Ausab); of Epstein-Barr virus, cytomegalovirus, and herpes simplex virus by fourfold rises in the respective antibody titres on complement fixation; and of non-A, non-B hepatitis by the exclusion of the above.

Each patient was followed up one, three, six, nine, and 12 months after admission and then at three monthly intervals for at least 18 months. Blood was taken at each visit for liver function tests and serological markers to be measured.

\section{Results}

From March 1983 to September 1986, 348 patients with acute viral hepatitis were admitted to this unit. 
Three patients who had viral hepatitis that was not caused by one of the three main types of virus (hepatitis A, hepatitis B, and non-A, non-B) have been excluded from further analysis (one caused by cytomegalovirus, and two caused by Epstein-Barr virus). In the remaining 345 patients the ages ranged from 3 months to 12 years and there were 281 (162 boys and 119 girls) with hepatitis A, 29 (19 boys and 10 girls) with hepatitis $B$, and 35 (23 boys and 12 girls) with non-A, non-B hepatitis. Table 1 gives the details of their age distribution. Boys were more commonly affected with all types of hepatitis than girls, and hepatitis A was the most common virus, though there was an increase in the incidence of hepatitis B and a decrease in that of non-A, non-B hepatitis with age.

The common presenting symptoms are shown in table 2. Children with hepatitis A had more systemic symptoms and jaundice than those with hepatitis $B$ or non-A, non-B hepatitis.

Table 3 shows the length of time to death, or recovery in the 332 patients who attended for follow up. There were no deaths among those with hepatitis $\mathrm{A}$, and most of them recovered within six

Table 1 Age distribution

\begin{tabular}{lclll}
\hline $\begin{array}{l}\text { Age } \\
\text { (years) }\end{array}$ & $\begin{array}{l}\text { Total } \\
\text { No }\end{array}$ & $\begin{array}{l}\text { No (\%) } \\
\text { with hepatitis } \\
\text { A }\end{array}$ & $\begin{array}{l}\text { No (\%) } \\
\text { with hepatitis } \\
B\end{array}$ & $\begin{array}{l}\text { No (\%) } \\
\text { with non- } A, \\
\text { non- } B \\
\text { hepatitis }\end{array}$ \\
\hline $0-4$ & 64 & $41(64)$ & $8(12)$ & $15(23)$ \\
$5-8$ & 112 & $99(88)$ & $6(5)$ & $\begin{array}{l}7(6) \\
13(8)\end{array}$ \\
$8-12$ & 169 & $141(83)$ & $15(9)$ & $35(10)$ \\
\hline Total & 345 & $281(81)$ & $29(8)$ & 35 \\
\hline
\end{tabular}

One patient with hepatitis caused by cytomegalovirus and two with hepatitis caused by Epstein-Barr virus have been excluded from this analysis.

Table 2 Clinical features

\begin{tabular}{lccc}
\hline & $\begin{array}{l}\text { No (\%) with } \\
\text { hepatitis } A \\
(n=281)\end{array}$ & $\begin{array}{l}\text { No (\%) with } \\
\text { hepatitis } B \\
(n=29)\end{array}$ & $\begin{array}{l}\text { No }(\%) \text { with } \\
\text { non-A, non-B } \\
\text { hepatitis } \\
(n=35)\end{array}$ \\
\hline Abdominal pain & $181(64)$ & $13(45)$ & $15(43)$ \\
Anorexia & $232(83)$ & $16(55)$ & $24(69)$ \\
Arthritis & $15(5)$ & $4(14)$ & $2(6)$ \\
Diarrhoea & $50(18)$ & $4(14)$ & $9(26)$ \\
Fever & $160(57)$ & $15(52)$ & $18(51)$ \\
Lethargy & $228(81)$ & $20(69)$ & $24(69)$ \\
Not jaundiced & $4(1)$ & $1(3)$ & $17(49)$ \\
Pale stools & $48(17)$ & $3(10)$ & $3(9)$ \\
Rash & $20(7)$ & $3(10)$ & $1(3)$ \\
Tea coloured urine & $239(85)$ & $23(79)$ & $19(54)$ \\
Vomiting & $201(72)$ & $13(45)$ & $20(57)$ \\
\hline
\end{tabular}

Table 3 Length of time to death, or to recovery in the 332 patients who attended for follow up

\begin{tabular}{ccll}
\hline & $\begin{array}{l}\text { No with } \\
\text { hepatitis } A \\
(n=270)\end{array}$ & $\begin{array}{l}\text { No with } \\
\text { hepatitis } B \\
(n=28)\end{array}$ & $\begin{array}{l}\text { No with } \\
\text { non- } A, \text { non- } B \\
\text { hepatitis } \\
(n=34)\end{array}$ \\
\hline $\begin{array}{l}\text { Died } \\
\text { Time to recovery }\end{array}$ & $\begin{array}{l}\text { (months): } \\
1\end{array}$ & 1 & 2 \\
3 & 90 & 1 & 12 \\
6 & 81 & 8 & 6 \\
9 & 35 & 8 & 5 \\
12 & 53 & 4 & 2 \\
15 & 5 & 3 & 2 \\
18 & 3 & 0 & 2 \\
21 & 3 & 2 & 1 \\
24 & 0 & 1 & 1 \\
$>24$ & 0 & 0 & 0 \\
\hline
\end{tabular}

Table 4 Time of seroconversion in 27 patients with hepatitis $B$

\begin{tabular}{lll}
\hline $\begin{array}{l}\text { Time after } \\
\text { diagnosis } \\
\text { (months) }\end{array}$ & $\begin{array}{l}\text { No (\%) negative } \\
\text { for hepatitis } B \\
\text { surface antigen }\end{array}$ & $\begin{array}{l}\text { No (\%) positive for } \\
\text { hepatitis B surface } \\
\text { antibody }\end{array}$ \\
\hline 0 & $2(7)$ & $2(7)$ \\
1 & $3(11)$ & $2(7)$ \\
3 & $20(74)$ & $16(59)$ \\
6 & $26(96)$ & $21(77)$ \\
9 & 0 & $24(89)$ \\
12 & 0 & $26(96)$ \\
$\geqslant 18$ & $26(96)$ & $26(96)$ \\
\hline
\end{tabular}

months. Patients with hepatitis B seemed to recover more slowly, and one patient with non-A, non-B hepatitis developed chronic persistent hepatitis.

Table 4 shows the hepatitis B surface antigen clearance rate, and the seroconversion rate. Only one patient became a chronic carrier of hepatitis B surface antigen, and his liver function was normal. Of the 34 patients with hepatitis $A$ and the nine with non-A, non-B hepatitis who were positive for hepatitis B surface antigen on admission, 27 and eight, respectively, became chronic carriers.

\section{Discussion}

There are few reports of studies of the aetiology and clinical course of hepatitis in children. ${ }^{12}$ Our study was carried out in an area where there is not only a high incidence of hepatitis but also a high incidence of hepatitis B in the general population. ${ }^{3}$ As in other countries, however, hepatitis $\mathrm{A}$ is the most common form in children. ${ }^{24}$ This suggests that children have contact with the hepatitis A virus early in childhood, which confirms the findings of a previous study that 
by the ages of 5,10 , and 15 years, $10 \%, 15 \%$, and $44 \%$, respectively already have antibodies to hepatitis $A$ virus. ${ }^{5}$ Our finding that hepatitis $B$ and non- $A$, non-B hepatitis were found only in $8 \%$ and $10 \%$ of our group of children with acute hepatitis is in contrast with the findings of others in adults. ${ }^{6}$

There are three principal modes of transmission of hepatitis B infection in Hong Kong: infection of newborn infants by mothers who are carriers, which accounts for the comparatively high incidence in infancy; transmission from friends and family members, which accounts for the second peak at about 11 to 15 years of age; and sexual transmission, which accounts for the pronounced increase in young adults. $^{3}$

Non-A, non-B hepatitis, which is rare in Italy, was comparatively common in our series accounting for $10 \%$ of the cases. ${ }^{1}$ As with hepatitis $\mathrm{B}$ it was more common in infants, then the incidence dropped before rising again after the age of about 10 years; in adults in Hong Kong it accounts for about $35 \%$ of cases. ${ }^{5}$ In the seven cases in our series who were also hepatitis B surface antigen positive, none had antidelta antibodies.

We confirm the findings of most reports that systemic symptoms were more common in patients with hepatitis A. It was noteworthy that jaundice was not a presenting feature in about half the cases of non-A, non-B hepatitis, and rashes and arthritis were more common in patients with hepatitis B.

We are also able to confirm from these data that patients with hepatitis $\mathrm{A}$ always recover, and do so more quickly than patients with hepatitis B. There are few data about the progression of acute hepatitis $\mathrm{B}$ to chronic liver disease in children, ${ }^{178}$ but Caporaso et al in Naples reported that two years after the acute attack there was histological evidence of chronic disease in 10 of 42 cases $(24 \%)$; they found chronic active hepatitis in four, chronic persistent hepatitis in one, and chronic lobular hepatitis in another. ${ }^{1}$ They did not study delta infection, which is common in Italy and rare in Hong Kong, and this may explain why none of our patients with hepatitis B went on to develop chronic liver disease and only one became a carrier of hepatitis B surface antigen.

The only case that progressed to chronic liver disease was of non-A, non-B hepatitis. The incidence varies from series to series, probably because there are at least three types of non- $\mathrm{A}$, non- $\mathrm{B}$ hepatitis; there is the type that is transmitted by blood (B type), the type that is transmitted by the coagulation factor, and the epidemic water borne type (A type). ${ }^{9}$ Chronic liver disease often follows the $B$ type, but rarely the $A$ type. It is likely that our non-A, non-B cases were of the B type. None of our patients had previously had a blood transfusion; the possible methods of transmission are from close members of the family, through intimate contact and sharing of household utensils and toothbrushes. Clusters of cases in households have been reported.

\section{References}

${ }^{1}$ Caporaso N, Coltorti M, Del Vecchio-Blanco C, et al. Acute viral hepatitis in childhood: aetiology and evolution. $J$ Pediatr Gastroenterol Nutr 1983;2:99-104.

2 Mowat AP. Viral hepatitis in infancy and childhood. Clin Gastroenteral 1980;9:191-208.

3 Chang WK, Yeoh EK. Hepatitis B infection in Hong Kong: a serological study of a Chinese population. Journal of the Hong Kong Medical Association 1985;37:27-30.

${ }^{4}$ Frösner GG, Papaevangelou G, Bütler R, et al. Antibody against hepatitis $\mathrm{A}$ in seven European countries. Am J Epidemiol 1979;110:63-9.

${ }^{5}$ Medical and Health Department Virus Unit, Hong Kong. Seroepidemiology of infection with hepatitis $A$ and $B$ virus in Hong Kong. Hong Kong, 1980.

6 Lai ST, Kan YS and Chang WK. An epidemiological survey of acute viral hepatitis in Hong Kong. Journal of the Hong Kong Medical Association 1986;38:25-6.

7 Gerety RJ, Schweitzer IL. Viral hepatitis type B during pregnancy, the neonatal period and infancy. $J$ Pediatr 1972;90:368-74.

8 Vittal SBV, Thomas W Jr, Clowdus BF. Acute viral hepatitis, course and incidence of progression to chronic hepatitis. Am J Med 1973;55:757-61.

9 Tabor E. The three viruses of non-A, non-B hepatitis. Lancet 1985;i:743-5.

Correspondence to Dr CB Chow, Paediatric A Unit, Princess Margaret Hospital, Hong Kong.

Accepted 18 July 1988 